\title{
Pengaruh Self Efficacy Dan Risk Taking Terhadap Intensi Berwirausaha Mahasiswa Universitas Tarumanagara
}

\author{
Enrico Filbert Gunawan dan Ida Puspitowati \\ Program Studi Manajemen, Fakultas Ekonomi Universitas Tarumanagara Jakarta \\ Email: Enricog.em@stu.untar.ac.id
}

\begin{abstract}
This study aims to find out the effect that occurs between Self Efficacy toward entrepreneurial intention, also the influence that occurs between Risk Taking toward entrepreneurial intention on Tarumanagara University Economics Faculty Student. This research uses quantitative method in which data are collected by researchers through direct survey with non-probability sampling (purposive sampling) technique to prospective respondents by giving questionnaires to 100 respondents on Tarumanagara University Economics Faculty Student. Data collection in this study uses a questionnaire method distributed online through google-form and testing the data from the questionnaire will be processed using the SPSS version 23 program. The results of this study indicate that there is a significant and positive influence on Self Efficacy to entrepreneurial intention, and significant positive influence on Risk Taking to Entrepreneurial Intention.
\end{abstract}

Keywords: Self Efficacy,Risk Taking, Intensi Berwirausaha

\begin{abstract}
Abstrak: Penelitian ini bertujuan untuk mengetahui pengaruh yang terjadi antara Self Efficacy terhadap Intensi Berwirausaha, demikian juga untuk menguji pengaruh yang terjadi antara Risk Taking terhadap Intensi Bewirausaha dan meneliti nya dalam Mahasiswa Fakultas Ekonomi Universitas Tarumanagara. Penelitian ini menggunakan metode kuantitatif dimana data dikumpulkan oleh peneliti melalui survei secara langsung menggunakan teknik nonprobability sampling dengan cara purposive sampling kepada calon responden dengan memberikan kuesioner terhadap 100 responden Mahasiswa Fakultas Ekonomi Universitas Tarumanagara. Pengumpulan data pada penelitian ini menggunakan metode kuesioner yang disebarkan secara online melalui google-form dan pengujian data hasil kuesioner akan diolah menggunakan bantuan program SPSS versi 23. Hasil penelitian ini menunjukkan bahwa terdapat pengaruh yang signifikan pada pada Self Efficacy dan Risk Taking terhadap Intensi Berwirausaha.
\end{abstract}

Kata kunci: Self Efficacy, Risk Taking, Intensi Berwirausaha

\section{LATAR BELAKANG}

Dunia kerja semakin hari menjadi semakin sempit, sementara masyarakat yang membutuhkan pekerjaan terus meningkat. Hal ini yang membuat munculnya banyak pengangguran. Menjadi pengangguran bukanlah hasil sebuah pilihan untuk tidak bekerja, tetapi akibat dari semakin sulitnya mencari pekerjaan. Menurut Badan Pusat Statistik ( BPS ) Tingkat pengangguran terbuka (TPT) di Indonesia per Februari 2018 berjumlah 6.87 juta orang atau 5,13\% Angka ini turun sekitar 2\% dibandingkan dengan Februari 2017 yang berjumlah 7,01 juta orang atau 5,33\% Meskipun mengalami perubahan yang positif namun capaian ini bukanlah suatu hal yang baik.Sedangkan menurut data yang diambil dari Badan Pusat Statistik 
(BPS), pada bulan Februari 2010 angka pengangguran terbuka mencapai 8,59 juta orang dengan 1,22 juta orang atau $14,24 \%$ diantaranya adalah pengangguran terdidik dengan kualifikasi pendidikan sebagai sarjana. Data BPS memperlihatkan, pada Februari dan Agustus 2009 , pengangguran sarjana masing-masing hanya $12,94 \%$ dan $13,08 \%$. Dalam rilis BPS per Februari ini mencatat jumlah pengangguran terbuka berdasarkan riwayat pendidikan tertinggi ditempati oleh pendidikan diploma I/II/III yang mencapai $15,71 \%$ dari 8,59 juta pengangguran. Sementara untuk pengangguran lain dengan angka pengangguran total 8,59 juta pengangguran masing-masing adalah lulusan universitas 14,2 \%, SMK 13,8 \%, SMA 11,9\%, SMP 7,55\%, dan SD ke bawah 3,71\%.

Dalam data terakhir yang dirilis Badan Pusat Statistik (BPS) yaitu pada bulan Agustus 2017, jumlah pengangguran terbuka mencapai 5,50\% dari jumlah keseluruhan penduduk Indonesia atau sekitar 12 juta penduduk yang diantaranya merupakan pengangguran terdidik dengan presentase sebesar 12,6\% untuk tingkat lulusan universitas. Hal ini menunjukan bahwa dari tahun ke tahun terdapat peningkatan jumlah pengangguran terdidik yang menjadi permasalahan yang tidak bisa dipandang sebelah mata. Dari data yang dihimpun oleh Badan Pusat Statistik (BPS) dapat disimpulkan bahwa masih tingginya tingkat pengangguran baik yang terbuka maupun yang terdidik. Sedangkan tingkat pengangguran yang tinggi juga menggambarkan tingkat kemiskinan yang tinggi di Indonesia.

Pemerintah masih harus melakukan banyak usaha untuk menurunkan tingkat kemiskinan di Indonesia. Salah satu cara yang ditempuh pemerintah untuk menekan tingkat kemiskinan adalah dengan mendukung keberadaan para pengusaha UMKM. UMKM menyumbangkan 99\% dalam jumlah pelaku usaha yang ada di Indonesia, serta mempunyai andil 99,6\% dalam penyerapan tenaga kerja (BPS, 2001). Dengan bantuan UMKM, tingkat pengangguran dapat berkurang dan dapat mempengaruhi tingkat pendapatan masyarakat. Penggambaran peran positif UMKM untuk perekonomian masyarakat menurut (Kuncoro, 2009) yaitu UMKM berperan penting sebagai penyumbang ekspor tertinggi terutama ekspor non migas.

Dalam konsep kewirausahaan, seorang wirausaha dipresepsikan sebagai orang yang mempunyai kreativitas dan semangat yang tinggi untuk bekerja. Selain itu, dalam menghasilkan sumber daya manusia yang berkualitas pada UMKM tidak terlepas dari peran kewirausahaan karena semakin ketatnya persaingan akan membuat pelaku usaha untuk bertindak kreatif agar mampu bertahan sehingga peran kewirausahaan penting bagi suatu UMKM. Menjdi wirausaha yang sukses diperlukan tidak hanya hard skill, tetapi juga soft skill. Hard skill mencakup pengetahuan dan kemampuan teknis, sedangkan soft skill mencakup pengelolaan kepribadian. Penyelarasan antara hard skill dan soft skill dapat meningkatkan kinerja para calon wirausaha sehingga usaha yang dimilikinya dapat berhasil.

Menjadi seorang wirausahawan yang sukses dibutuhkan waktu dan usaha yang banyak. Salah satu usaha yang dapat dilakukan adalah mengikuti pendidikan mengenai kewirausahaan yang banyak ditawarkan oleh universitas-universitas di Indonesia, salah satunya adalah Universitas Tarumanagara. Salah satu konsentrasi pendidikan yang ditawarkan oleh Universitas Tarumanagara adalah konsentrasi kewirausahaan. Dalam konsentrasi kewirausahawan, mahasiswa tidak hanya diberikan ilmu tentang berwirausaha, tapi juga caracara yang baik dan bagaimana caranya menjadi seorang wirausahawan yang sukses.

Self Efficacy yang berarti kepercayaan diri sangat dibutuhkan dalam memulai suatu hal yang baru, terutama dalam memulai atau merintis suatu usaha. Dengan Self Efficacy yang tinggi berarti seorang wirausaha percaya pada kemampuan dirinya sendiri untuk membangun suatu usaha baru.

Seorang wirausahawan juga dituntut untuk memiliki kemampuan Risk Taking dan berani menghadapi rintangan. Dalam perkembangan dan perjalanan usaha, kita pasti akan menghadapi kendala dan kesulitan, baik kendala yang kecil maupun yang besar. Selain mendapatkan keuntungan dalam berbisnis, memiliki usaha berarti siap juga untuk menerima risiko usaha. Bahkan, bagi suatu usaha yang telah sukses sekalipun, bukan tidak mungkin tetap 
menghadapi kendala. Maka dari itu kemampuan Risk Taking sangat dibutuhkan oleh seorang wirausaha untuk mengatasi kendala-kendala dalam menjalankan suatu usaha.

Semakin besar kepercayaan diri seseorang, maka semakin besar keyakinannya untuk sanggup mengambil keputusan dan semakin besar pula keyakinanya untuk mencoba suatu pekerjaan yang dinilai berisiko.

\section{KAJIAN TEORI}

Kewirausahaan adalah suatu nilai yang diperlukan untuk memulai suatu usaha (startup phase) dan perkembangan usaha (verture growth) (Soeharto Prawiro, 1997). Sedangkan menurut (Harvey Leibenstein, 1968) Kegiatan kewirausahaan meliputi diperlukan untuk membuat atau melaksanakan perusahaan ketika semua pasar belum teridentifikasi dengan jelas, atau komponen fungsi produksi tidak sepenuhnya diketahui. Hal lain disampaikan oleh (Thomas W. Zimmerer, 1996), kewirausahaan adalah hasil dari suatu disiplin, proses sistematis penerapan krativitas dan keinovasian dalam memenuhi kebutuhan dan peluang di pasar. (Israel Kirzner, 1979) mengatakan wirausahwan mengenali dan bertindak terhadap peluang pasar. Entrepreneurship Center at Miami University of Ohio mengatakan bahwa kewirausahaan sebagai proses mengidentifikasi, mengembangkan, dan membawa visi kedalam kehidupan. Visi tersebut bisa berupa ide inovatif, peluang, cara yang lebih baik dalam menjalankan sesuatu. Hasil akhir dari proses tersebut adalah penciptaan usaha baru yang dibentuk pada kondisi resiko atau ketidakpastian.

Intensi merupakan suatu prediktor dalam menentukan perilaku seseorang, sebelum terjadinya suatu perilaku. Intensi merupakan suatu usaha untuk mencapai tujuan tertentu (Chaplin, 1999). (Corsini, 2002) mengatakan intensi adalah keputusan bertindak dengan cara tertentu, atau dorongan untuk melakukan suatu tindakan, baik itu secara sadar atau tidak sadar. Berbeda dengan Corsini pendapat lain dikemukakan oleh (Sudarsono, 1993) yang menyatakan bahwa intensi adalah niat, tujuan, keinginan untuk melakukan sesuatu, mempunyai tujuan. Sedangkan (Ajzen, 2005), menyatakan bahwa intensi adalah indikasi seberapa kuat keyakinan seseorang akan mencoba suatu perilaku, dan seberapa besar usaha yang akan digunakan untuk melakukan perilaku. Menurut Theory of Planned Behavioral, intensi untuk melakukan suatu perilaku merupakan prediktor paling kuat bagi munculnya perilaku tersebut.

(Bandura, 1997) mengatakan bahwa indikator Self Efficacy terdiri dari: melihat orang lain, pengalaman, persuasi sosial, dan faktor fisiologis. Melihat atau mengamati aktivitas seseorang secara berulang-ulang akan memudahkan kita untuk melakukan pekerjaan yang samaseperti yang pernah kita lihat dilakukannya (Modelling). (Bandura, 1997) proses demikian lebih efektif ketika seseorang melihat dirinya sama dengan modelatau yang menjadi modelnya.Jika suatu model yang dirasa seperti dirinyamemiliki kemampuan yang sama dan berhasil, hal ini akan meingkatkan Self Efficacy si pemodel. (Bandura, 1997) pengalaman (experience) yaitu penguasaan suatu pekerjaan atau tugas karena sudah pernah melakukan pekerjaan tersebut sebelumnya.

Kecenderungan dalam Risk Taking merupakan salah satu dari sifat atau karakteristik yang ada pada wirausaha. Beberapa ahli menklasifikasi kecenderungan dalam Risk Taking sebagai bagian yang tidak terpisahkan dari wirausaha.

Motif utama berwirausaha diindikasikan dengan Risk Taking (Shane et al., 2003).Ciri pribadi kecenderungan Risk Taking berhubungan dengan optimis dan pesimis yaitu: (1) Kecenderungan mengambil risiko menggerakkan persepsi risiko yang lebih tinggi. (2) Toleransi ambiguitas juga mendorong persepsirisiko yang lebih tinggi. (3) Locus of control berperan dalam mengendalikan situasi dan risiko. (4) Kebebasan tidak memiliki hubunganyang jelas dengan persepsi risiko. (5) Kebutuhan akan berprestasi yang tinggi akan mentoleransi risiko sehingga persepsi terhadap risiko menjadi rendah. (6) Pemilik usaha yang memiliki sikap 
optimis merasa yakin mampu mengendalikan situasi sehingga cenderung berani untuk mengambil risiko.

Berdasarkan konsep (Hisrich et al., 2008), didalam diri seorang wirausaha yang mempunyai Self Efficacy yang tinggi adalah orang yang percaya dengan kemampuannya dan akan menunjukkan pencapaian hasil yang terbaik. Hal ini menunjukan pengaruh Self Efficacy dalam menentukan kesuksesan seseorang. Self Efficacy yang tinggi akan memberikan insiatif dan ketekunan untuk meningkatkan usaha dan kinerja seorang wirausaha. Self Efficacy yang rendah akan mengurangi usaha dan kinerja seseorang. Self Efficacy mempengaruhi pilihan seseorang dan besarnya usaha yang akan dilakukan. Seorang wirausaha yang mempunyai Self Efficacy positif akan berkreasi membuka sebuah usaha baru.

Menurut (Douglas dan Shepherd dalam Mahesa, 2012) untuk memprediksi keinginan seseorang menjadi entrepreneur dapat menggunakan toleransi akan risiko, dikatakan bahwa semakin toleran seseorang dalam menghadapi risiko, semakin meningkat keinginan orang tersebut untuk menjadi seorang entrepreneur Motif utama berwirausaha diindikasikan dengan pengambilan risiko (Shane et al., 2003). Demikian pula hasil penelitian yang dilakukan oleh (Barbosa, 2007) bahwa keberanian seseorang dalam mengambil risiko yang tinggi maka Intensi Berwirausaha yang dimiliki juga lebih tinggi.

Kerangka Pemikiran dan Hipotesis. Karakteristik yang dimiliki seseorang dapat mempengaruhi niat dan keinginan seseorang untuk berwirausaha. Seseorang yang memiliki Self Efficacy yang tinggi merupakan orang yang percaya dengan kemampuannya dan akan menunjukkan pencapaian hasil yang terbaik. Self Efficacy yang tinggi akan memberikan insiatif dan ketekunan untuk meningkatkan usaha dan kinerja seorang wirausaha.

Risk Taking merupakan hal yang penting dalam berwirausaha. Keberanian seseorang dalam mengambil risiko yang tinggimaka Intensi Berwirausaha yang dimiliki juga akan lebih tinggi.

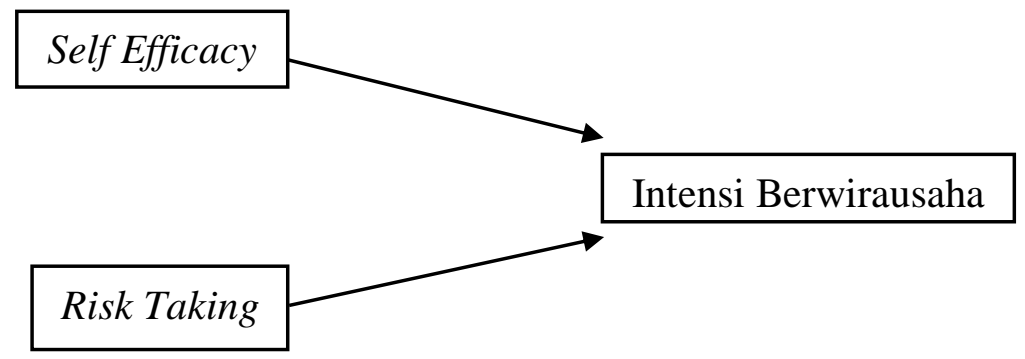

Gambar 1. Model Penelitian

Berdasarkan pola gambar 1, maka didapatkan hipotesis berikut ini:

H1: Terdapat pengaruh yang positif dan signifikan antara Self Efficacy terhadap Intensi Berwirausaha.

H2: Terdapat pengaruh yang positif dan signifikan antara Risk Taking terhadap Intensi Berwirausaha.

\section{METODOLOGI}

Penelitian ini menggunakan desain penelitian deskriptif menggunakan kuesioner karena tujuan utama penelitian ini adalah mendeskripsikan dan menginterpretasi objek sesuai 
dengan apa adanya dan membuktikan pengaruh antar variabel Self Efficacy dan Risk Taking terhadap Intensi Berwirausaha Mahasiswa Fakultas Ekonomi Universitas Tarumanagara

Pengumpulan data pada penelitian ini menggunakan metode kuesioner yang disebarkan secara online melalui google-form kepada 100 responden Mahasiswa Fakultas Ekonomi Universitas Tarumanagara dan pengujian data hasil kuesioner akan diolah menggunakan bantuan program SPSS versi 23. Dalam penelitian ini menggunakan Uji Statistik Deskriptif untuk menguji data sampel, kemudian melakukan uji asumsi klasik yang terdiri dari Uji Normalitas, Uji Multikolinieritas, Uji Heterokedastisitas,. Sedangkan uji hipotesis menggunakan Uji t, Uji F dan Uji Koefisien Determinasi. Pengukuran variabel-variabel dalam penelitian ini mengacu pada penelitian sebelumnya, antara lain sebagai berikut:

Tabel 1. Indikator Kuesioner tiap Variabel

\begin{tabular}{|c|c|}
\hline Variabel & Indikator \\
\hline Self Efficacy & 7 item \\
\hline Risk Taking & 4 item \\
\hline Intensi Berwirausaha & 7 item \\
\hline
\end{tabular}

\section{HASIL UJI STATISTIK}

Uji Validitas. Hasil uji validitas menunjukkan hasil perhitungan dengan menggunakan rumus model alpha yang diolah dengan bantuan Program SPSS dan didapatkan hasil pada kolom Corrected Item Total Correlation pada tabel uji validitas tiap variabel bahwa setiap item pernyataan untuk semua variabel independen dan variabel dependen yaitu hasil yang didapatkan dari setiap pernyataan yang diuji adalah sebesar $\geq 0,3$ maka setiap variabel dapat dinyatakan valid.

Uji Reliabilitas. Hasil uji reliabilitas pada variabel Self Efficacy, Risk Taking dan Intensi Berwirausaha masing-masing memperlihatkan nilai Alpha Cronbach sebesar 0,834, 0,634,dan 0,821 maka dapat disimpulkan bahwa seluruh variabel dapat dinyatakan reliabel karena setiap variabel tersebut memiliki nilai Cronbach Alpha melebihi 0,6.

\section{Hasil Uji Asumsi Analisis Data}

Uji Normalitas. Dapat dilihat berdasarkan hasil uji normalitas menggunakan SPSS pada tabel 4.6, didapatkan nilai sig sebesar 0.006, sehingga residual data dapat dikatakan terdistribusi dengan normal, karena memenuhi syarat yaitu Sig > 0,05 $(0,154>0,05)$.

Uji Multikolinearitas. Berdasarkan uji multikolinieritas yang telah diuji dengan menggunakan SPSS, nilai VIF dari ketiga variabel mendapatkan nilai sebesar 1,203 yang dinyatakan lebih kecil dari 10, sehingga pada penelitian ini tidak terdapat gejala multikolinieritas di antara variabel bebas.

Uji Heteroskedastisitas. Hasil dari grafik scatterplot berdasarkan hasil pada SPSS versi 20 terlihat titik-titik menyebar secara acak dan tidak menunjukkan adanya pola tertentu seperti menyempit atau melebar. Hal ini menunjukkan bahwa model regresi ini baik karena tidak terjadi adanya heteroskedastisitas. Dari hasil analisis secara keseluruhan, maka dapat disimpulkan bahwa model regresi ganda dapat digunakan untuk menganalisis data karena telah 
memenuhi syarat, yaitu. (1) Residual terdistribusi secara normal. (2) Tidak terdapat multikolinieritas. (3) Tidak terdapat heteroskedastisitas

Hasil Analisis Regresi Berganda. Untuk mengetahui persamaan regresi berganda dapat dilihat pada tabel berikut:

\begin{tabular}{|c|c|c|c|c|c|}
\hline & \multirow[b]{2}{*}{ Model } & \multicolumn{2}{|c|}{ Unstandardized Coefficients } & \multirow{2}{*}{$\begin{array}{c}\begin{array}{c}\text { Standardized } \\
\text { Coefficients }\end{array} \\
\text { Beta }\end{array}$} & \multirow[b]{2}{*}{$\mathrm{t}$} \\
\hline & & B & Std. Error & & \\
\hline \multirow[t]{3}{*}{1} & (Constant) & 11.302 & 3.051 & & 3.705 \\
\hline & Self_Efficacy & .396 & .104 & .369 & 3.807 \\
\hline & Risk_Taking & .410 & .193 & .206 & 2.126 \\
\hline
\end{tabular}

Berdasarkan hasil pengujian diperoleh model persamaan regresi untuk hubungan antara variabel dependen dan variabel independen pada penelitian ini adalah sebagai berikut :

$$
\begin{aligned}
\text { IB } & =\mathbf{1 1 . 3 0 2}+\mathbf{0 . 3 9 6 S E}+\mathbf{0 . 4 1 0 R T} \\
\mathrm{IB} & =\text { Intensi Berwirausaha } \\
\mathrm{SE} & =\text { Self Efficacy } \\
\mathrm{RT} & =\text { Risk Taking }
\end{aligned}
$$

Serta didapatkan hasil yaitu variabel independen yang memberikan pengaruh terbesar kepada Intensi Berwirausaha yaitu variabel Risk Taking dengan nilai Beta sebesar 0,410 dan yang memberikan pengaruh kedua terhadap Intensi Berwirausaha merupakan variabel Self Efficacy dengan nilai Beta sebesar 0,396.

\section{Hasil Uji Hipotesis}

Uji F (ANOVA). Dilihat dari hasil uji F pada SPSS, Sig $\leq \alpha(0,000 \leq 0,05)$, maka Ho tidak ditolak, berarti dapat disimpulkan terdapat pengaruh yang signifikan antara Self Efficacy dan Risk Taking terhadap Intensi Berwirausaha dikarenakan angka sig lebih kecil dari nilai $\alpha$ yang ditentukan.

Uji t. Berdasarkan tabel 4.9 dapat diketahui bahwa nilai sig untuk X1 adalah sebesar $0.000<$ 0,05 , yang berarti terdapat pengaruh yang signifikan antara variabel Self Efficacy terhadap Intensi Berwirausaha. Untuk variabel Risk Taking, diketahui nilai sig untuk X2 adalah sebesar $0<0,05$, sehingga dapat disimpulkan bahwa Ho ditolak, yang berarti terdapat pengaruh yang signifikan antara variabel Risk Taking terhadap Intensi Berwirausaha.

Hasil Koefisien Determinasi $\left(\mathbf{R}^{2}\right)$. Hasil dari $\mathrm{R}^{2}$ adalah 0.441 sehingga mengindikasikan keterbatasan kemampuan variabel-variabel independen dalam menjelaskan variabel dependen dan mengandung arti bahwa pengaruh variabel Self Efficacy dan Risk Taking secara simultan terhadap Intensi Berwirausaha adalah sebesar44.1\% sisanya sebesar 55.9\% dapat dijelaskan oleh variabel lain. 


\section{DISKUSI}

Hasil pengujian dari hipotesis menunjukkan bahwa $\mathrm{H}_{1}$ diterima, sehingga dapat dikatakan bahwa terdapat pengaruh yang positif dan signifikan antara variabel Self Efficacy terhadap Intensi Berwirausaha. Hal ini sejalan dengan apa yang telah disampaikan oleh (Wijaya, 2008) yang menemukan bahwa Self Efficacy secara simultan berpengaruh terhadap intensi dan perilaku berwirausaha. Hasil ini juga memperkuat penelitian yang terlebih dahulu dilakukan oleh (Bandura, 1997) yang meyakini bahwa self efficacy menentukan apakah seseorang akan menunjukkan perilaku tertentu,sekuat apa seseorang tersebut dapat bertahanpada saat menghadapi kesulitan dan bagaimana kesuksesan atau kegagalan dalam mejalankan tugas akan berimbas pada perilakunya di masadepan. Hasil pengujian ini juga didukung dengan penelitian yang telah dilakukan oleh (Ayodele, 2013) dalam penelitiannya di Ogun-Nigeria yang menyatakan bahwa Self Efficacy berpengaruh secara signifikan terhadap intensi berwirausaha. Hasil pengujian ini juga sejalan dengan penelitian terdahulu yang telah dilakukan oleh (Sarwoko, 2011) yang menjelaskan bahwa Self Efficacy memiliki pengaruh pada intensi berwirausaha mahasiswa, semakin..meningkat rasa percaya diri dan mental mahasiswa maka semakin tinggi perannya untuk meningkatkan intensi berwirausaha pada mahasiswa.

Dilihat pada hasil pengujian $\mathrm{H}_{2}, \mathrm{H}_{2}$ diterima yang berarti terdapat pengaruh yang positif dan signifikan antara variabel Risk Taking terhadap Intensi Berwirausaha. Hal ini diperkuat dengan penelitian terdahulu yang telah dilakukan Douglas dan Shepherd (Mahesa, 2012) yang mengatakan bahwa untuk memprediksikeinginan seseorang menjadi entrepreneur dapat menggunakan toleransi akan risiko, dikatakan bahwa semakin toleran seseorang dalam menghadapi risiko,semakin meningkat keinginan orang tersebut untuk menjadi seorang entrepreneur. Hasil penelitian ini juga sejalan dengan penelitian yang dilakukan oleh oleh (Vemmy, 2012) yang mengatakan variabel Risk Taking memiliki pengaruh yang signifikan terhadap Intensi Berwirausaha. (Widhari, 2012) juga mengatakan bahwa Risk Taking memiliki pengaruh positif dan signifikan terhadap Intensi Berwirausaha.Kecenderungan untuk berani mengambil risiko dan kemandirian, keluarga menunjukkan niat besar mereka untuk memulai berwirausaha (Ertuna dan Gurel, 2010). Demikian pula hasil penelitian yang dilakukan oleh (Barbosa, 2007) bahwa keberanian seseorang dalam mengambil risiko yang tinggimaka IntensiBerwirausaha yang dimiliki juga lebih tinggi.

\section{PENUTUP}

Berdasarkan hasil analisis yang telah dilakukan dalam penelitian ini menyatakan terdapat pengaruh positif dan signifikan antara Self Efficacy terhadap Intensi Bewirausaha serta terdapat pengaruh positif dan signifikan antara Risk Taking terhadap Intensi Berwirausaha. Berdasarkan hasil dari kesimpulan dan pembahasan dalam penelitian di atas, maka saran yang dapat penulis sampaikan berdasarkan analisis yang telah dilakukan yaitu Meningkatkan pemahaman dan pembelajaran tentang kewirausahaan terhadap Mahasiswa Fakultas Ekonomi Universitas Tarumanagara, khususnya Mahasiswa S-1 Manajemen dan Akuntansi, sehingga dapat lebih memahami apa saja yang dapat berpengaruh terhadap intensi berwirausaha. Kemudian penelitian yang selanjutnya diharapkan dapat memperbanyak jumlah sampel yang akan digunakan sehingga akan lebih mendekati lagi gambaran hasil dan gambaran kondisi yang sebenarnya. Penelitian yang selanjutnya diharapkan juga memperluas ruang lingkup sampel yang akan digunakan sehingga dapat menggambarkan hasil penelitian secara lebih aktual. 


\section{DAFTAR PUSTAKA}

Abdullah, Ridwan. (2015). Pembelajaran Saintifik untuk Implementasi Kurikulum 2013. Jakarta: PT Bumi Aksara.

Ayodele, K. O. (2013). Organizational. "Commitment and Turnover Intentio among Private Universities".

Azjen. I. (2005). Attitude, Personality, and Behavior. Buckingham: Open University Press, Milton Keynes.

Badan Pusat statistik. (2018). Persentase penduduk miskin Maret 2018 turun menjadi 9,82 persen. Retrieved from (www.bps.go.id/16-07-2018)

Baird, Inga Skromme and Howard Thomas. (1985). "Toward a Contingency Model of Strategic Risk Taking", Academy of management review,10,41-46.

Bandura, A. (1997). Social Learning Theory. New Jersey : Englewood Cliffs Prentice Hall.

Barbosa, M.T., Dkk. (2005). Applied and Environmental Microbiologi: Screening for Bacillus Isolates in The Broiler Gastrointestinal Tract. Vol 71. No. 2. American Society for Mikrobiologi. Amerika.

Chaplin, S.P. (1999). Kamus Lengkap Psikologi. Jakarta: PT. Raja Grafindo Persada.

Corsini, Ray. (2002). The Dictionary of Psychology. London: Brunner/Rout Ledge.

Douglas, E. J., and Shepherd, D. A. (2012). Entrepreneurship as a Utility Maximizing Response . Journal Of Business Venturing, 15, 231-25.

Ertuna, Gurel, (2010). The moderating role of higher education on entrepreneurship vol 53 Iss 5 pp. 387-402. Turkey: Bilkent University.

Gasse, Y. (1982)."Elaborations on the Psychology of the Entrepreneur," in Encyclopedia of Entrepreneurship.Eds. C. A. Kent, D. L. Sexton, and K. H. Vesper. Englewood Cliffs, NJ: Prentice Hall, 209-223.

Indarti. (2008). Intensi Kewirausahaan Mahasiswa: Studi PerbandinganAntara Indonesia, Jepang dan Norwegia. Jurnal Ekonomika dan Bisnis Indonesia, Vol. 23, No. 4, Oktober 2008.

Katz, J., and W. Gartner. (1988). Properties of emerging organizations. Academy of Management Review 13 (3): 429-441.

Kirzner, Israel M. (1979). Perception, Opportunity, and Profit: Studies in the Theory of Entrepreneurship. Chicago: University of Chicago Press.

Leibenstein Hervey. (1968). "Entrepreneurship and Development" The American Economic Review, Vol. 58, No. 2, Papers and Proceedings of the Eightieth Annual Meeting of the American Economic Association

Luthans, Fred. (2008.) Organizztional Behavior. McGraw-Hill Companies,Inc. New. York.

Malhotra, N.K. (2014). Basic Marketing Research. Pearson Education. England

Nursito, S., dan Nugroho, A. J. (2013). Analisis pengaruh interaksi pengetahuan kewirausahaan dan efikasi diri terhadap intensi kewirausahaan. Kiat Bisnis.

Sarwoko. (2008). Kajian empiris entrepreneurial intention mahasiswa.

Shane, et al. (2003). Entrepreneurial Motivation. Human Resource Management Review, Vol.13, pp. 257-279. Retrieved from Elsevier Science Inc.

Soeharto, Prawirokusumo. (1997). Peranan Perguruan Tinggi Dalam Menciptakan WirausahaWirausaha Tangguh. Makalah Seminar. Jatinangor : PIBI-IKOPIN dan FNST.

Sudarsono. (1993). Kamus Filsafat dan Psikologi. Jakarta: Rineka Cipta

Sugiyono, (2001). Metode Penelitian, Bandung: CV Alfa Beta

Tubbs, M,E. dan Ekeberg, S. E. (1991). "The role of Intentions work and motivation : implications for goal setting theory and research" Academy of Management Review. Vol. 16.

Vemmy, C. (2012). "Faktor-Faktor yang Mempengaruhi Intensi Berwirausaha Siswa SMK". Jurnal Pendidikan Vokasi, Vol 2, No.1. p.117-125. 
Wijaya, T. (2008). Hubungan Adversity Intellegence dengan Minat Berwirausaha. Jurnal, vol 9, no 2 Yogyakarta.

Zimmerer, W. Thomas Et al. (1996). Entrepreneurship and The New Venture Formation. Prentice Hall Inc. New Jersey. Zimmerer, W. Thomas Et al. 1996. Entrepreneurship and The New Venture Formation. Prentice Hall Inc. New Jersey. 